\title{
MEDIAN LETHAL CONCENTRATION (LC-50) INSEKTISIDA DIKLOROMETAN PADA NENER BANDENG (Chanos-chanos Forks)
}

\author{
Natalie D. Rumampuk, Sandra Tilaar, Stenly Wullur \\ Staf Pengajar pada Program Studi IImu Kelautan, \\ Fakultas Perikanan dan IImu Kelautan. UNSRAT. Manado 95115.
}

\begin{abstract}
The result showed that the median of the lethal concentration (LC-50) of dichloromethane insecticides on nener milkfish (Chanos-chanos Forsk) for 12 hours and 24 hours are $0.786 \mathrm{ppm}$, and $0.287 \mathrm{ppm}$, respectively. The increasing tendency of the time there is less lethalconcentration values, whereas the higher concentration, then the sooner the death of test organisms.
\end{abstract}

Keywords: dichloromethane, LC-50, milkfish fry.

\section{PENDAHULUAN}

Kemajuan teknologi memberikan manfaat pada peningkatan taraf hidup manusia, namun di sisi lain kemajuan teknologi dapat juga memberikan dampak negatif yang secara langsung merugikan manusia itu sendiri. Hasil dari aktivitas manusia sebagai tanda adanya kemajuan teknologi dalam bidang industri, pertambangan, dan sebagainya dapat mengakibatkan munculnya beraneka ragam zat yang berbahaya bagi lingkungan hidup dan pada akhirnya dapat merusak lingkungan. Bahan-bahan polutan yang berasal dari buangan pertambangan dan industri berupa limbah yang dibuang ke perairan dapat mempengaruhi dan mengganggu fisiologi serta morfologi tumbuhan maupun hewan (Rompas, 1994).

Salah satu kemajuan teknologi yang saat ini sedang berkembang adalah teknologi di bidang kimia yang memberikan kontribusi berarti pada sektor indrustri, pertanian, peternakan, perikanan, pertambangan, sektor kehutanan, dan lain-lain. Kegiatan yang dilakukan khususnya menyangkut pengunaan bahan kimia tanpa disadari telah menyebabkan organisme di lingkungan itu. Salah satu bahan kimia yang banyak digunakan dalam pelaksanaan kegiatan tersebut adalah pestisida.

Pestisida adalah bahan kimia bersifat racun yang sering digunakan dalam bidang pertanian khususnya untuk memberantas hama, gulma, dan penyakit pada tanaman serta meningkatkan produksi pertanian. Bahan-bahan kimia yang digunakan untuk memberantas atau mencegah hama air, jasad renik dalam rumah tangga, bangunan, dan alat-alat pengangkut serta binatang-binatang yang mengakibatkan penyakit pada manusia dan hewan, juga termasuk dalam pestisida (Rompas dan Sunarjo, 1989). Meskipun telah dibuat peraturan tentang tata cara pengunaan pestisida yang benar, akan tetapi aplikasi pemakaiannya oleh petani sering tidak terkontrol sehingga menimbulkan berbagai dampak negatif (Satta, 1974).

Diklorometan merupakan salah satu bahan dasar insektisida organoklorin yang sedang dikembangkan untuk mengantikan peran DDT yang telah dilarang pengunaannya. Bahan ini dikembangkan dengan harapan akan lebih efektif dan ramah lingkungan serta memiliki efek yang kecil terhadap organisme bukan sasaran. Namun, sampai saat ini masih kurang informasi mengenai konsentrasi yang aman bagi organisme laut khususnya ikan. Sehubungan dengan hal tersebut, untuk mengetahui tingkat keamanan pengunaan insektisida diklorometan terhadap organisme laut perlu dilakukan uji awal toksisitas insektisida diklorometan, yakni dengan pengujian lethal konsentrasi (LC-50).

Organisme uji yang digunakan untuk maksud tersebut adalah ikan bandeng (Chanos-chanos Forsk) karena ikan ini pada tahap nener merupakan salah satu organisme perairan intertidal yang sensitif terhadap berbagai polutan. Selain itu, organisme ini menempati habitat yang terdistribusi 
Insektisida Diklorometan pada Nener Bandeng

secara luas sehingga mudah didapat dan memiliki nilai ekonomis penting.

\section{METODOLOGI PENELITIAN}

Hewan uji yang digunakan dalam percobaan ini adalah nener bandeng (Chanos-chanos Forsk), sedangkan bahan uji yang digunakan adalah insektisida diklorometan standart. Air laut untuk budidaya diambil di pantai Malalayang salinitas 35 $\%$ kemudian diencerkan sampai diperoleh salinitas $15 \%$.

Kondisi lingkungan percobaan (kondisi laboratorium), seperti suhu, salinitas, dan $\mathrm{pH}$ diukur selama penelitian berlangsung. Untuk proses aklimatisasi Ikan Bandeng dipelihara dalam wadah akuarium dan diberi aerasi. Hewan uji diaklimatisasi selama 1 minggu sebelum percobaan dilakukan dan diberi makan berupa kuning telur 1 kali sehari.

Percobaan dilakukan dengan sistem statis (air tidak mengalir). Daya racun (toksisitas) bahan uji yang terkandung dalam hewan uji dihitung berdasarkan nilai Median Lethal Concentration (LC-50). Percobaan dilakukan dalam 2 tahap menurut panduan Buhagiar dan Abel (1991) dan Dinnel (1994). Kedua tahap tersebut adalah sebagai berikut:

\section{Tahap 1: Uji Pendahuluan}

Pecobaan pada tahap pendahuluan ini bertujuan untuk mencari kisaran konsentrasi krisis bahan uji yang akan digunakan untuk penentuan LC-50. Hewan uji sebanyak 10 individu dimasukkan ke dalam setiap gelas becker yang berisi $250 \mathrm{ml}$ air laut dengan konsentrasi bahan uji adalah 0,01 ; 0,$1 ; 1 ; 10 \mathrm{ppm}$, ditambah kontrol (0 ppm). Selama percobaan berlangsung hewan uji tidak diberi makan. Pengamatan dilakukan pada jam ke-3, 6, 12, 24, 36, 48 yang mati dicatat. Pengujian dihentikan setelah mencapai jam ke-48. Hewan uji yang mati pada waktu pengamatan segera dikeluarkan dari media uji untuk menghindari kemungkinan perubahan kualitas air yang bukan disebabkan oleh bahan uji. Hewan uji diamati pada tiap konsentrasi dan dihitung secara kumulatif dalam tiap jam. Disamping itu diamati pula tingkah laku hewan uji dalam wadah yang diberi perlakuan.

\section{Tahap 2: uji Penentuan LC-50}

Setelah kisaran konsentrasi krisis diklorometan diketahui, maka dipilih lima konsentrasi yang berbeda, yaitu: 0,$15 ; 0,35$; 0,$55 ; 0,75$ dan $0,95 \mathrm{ppm}$ ditambah kontrol (0 ppm). Kelima konsentrasi tersebut selanjutnya digunakan dalam penetuan LC-50 (Abel, 1991; Dinnel, 1994).

Hewan uji sebanyak 10 individu dimasukan ke dalam setiap wadah percoban (6 wadah uji) yang berisi $250 \mathrm{ml}$ air laut dan bahan uji dengan konsentrasi yang telah ditentukan, setiap perlakuan dilakukan tiga kali ulangan. Pengamatan dilakukan pada jam ke-3, 6, 12, 24, 36, 48, 60, 72, 84, dan 96 yang mati dicatat. Hewan uji diamati pada tiap konsentrasi dan dihitung secara kumulatif dalam tiap jam.

Median letal konsentrasi (LC-50) untuk masing-masing bahan uji dihitung dengan menggunakan program komputer Analisa Probit dengan nama Toxicologist v.1.0 menurut Finney (1971). Sedangkan untuk mengetahui kelayakan pelaksanaan percobaan dilakukan dengan kontrol mortalitas (Abbot 1925 dalam Abel 1991) yang akan digunakan, yaitu:

$$
\mathrm{C}=\frac{(\mathrm{O}-\mathrm{X})}{(100-\mathrm{X})}
$$

(C-mortalitas; O-Persentase mortalitas; X-\% dari hewan yang mati pada waktu pengamatan tertentu)

\section{HASIL DAN PEMBAHASAN}

Hasil uji pendahuluan diperoleh kisaran konsentrasi selama 48 jam yaitu 0,1-1 ppm. Dari percobaan penentuan LC50 telah diperoleh nilai rata-rata prosentase mortalitas yakni pada konsentrasi 0,15 ppm hewan uji yang mati sebesar $80 \%$ dan pada konsentrasi $0,35 \mathrm{ppm}$ hewan uji yang mati sebesar $96,6 \%$. Sedangkan pada konsentrasi 0,$55 ; 0,75$ dan $0,95 \mathrm{ppm}$ semua organisme uji tidak dapat bertahan hidup (tabel 1), hasil analisis data untuk nilai LC50 diklorometan terhadap nener bandeng sebagai hewan uji diperlihatkan pada tabel 2.

Nilai LC (Lethal Concentration) ditentukan untuk tujuan penelitian nilai ambang batas yang layak di suatu lingkungan penelitian (Sprague, 1969). Berdasarkan hasil analisis probit diperoleh nilai konsentrasi lehthal (LC-50) diklorometan (Insektisi- 
da Organoklorin) terhadap nener bandeng (Chanos-chanos Forsk) untuk uji 12 jam adalah 0,786 ppm, dengan demikian dapat diterima di lingkungan perairan. Sedangkan untuk waktu uji 24 jam adalah 0,287 sehingga dapat dikatakan pula bahwa konsentrasi yang dapat diterima di lingkungan perairan adalah di bawah konsentrasi 0,287 ppm. Hasil penelitian membuktikan bahwa nilai konsentrasi lethal menurun dengan bertambahnya waktu. Hal ini dikarenakan semakin bertambahnya waktu maka daya tahan tubuh dari nener bendeng terhadap insektisida diklorometan semakin kuat.

Selama waktu uji 3, 6, 36, 48, 60, 72 dan 96 jam LC-50 diklorometan tidak dapat ditentukan (tidak terderminasi). Hal ini disebabkan karena pada waktu uji 3 dan 6 jam dengan konsentrasi-konsentrasi yang ada, hewan uji yang mati belum melebihi $50 \%$. Sedangkan pada waktu uji $36,48,60,72$ dan 96 jam pada konsentrasi terendah 0,15 ppm kematian hewan uji sudah melebihi $50 \%$, sehingga tidak dapat dipetakan pada grafik.

Penelitian mengenai LC-50 juga telah dilakukan oleh Landeng (1999) dengan mengunakan bahan uji insektisida organoklorin Endosulfan pada hewan uji yang sama, nilai LC-50 jam ke-12, 24, 48, 60, 72, 84 dan 96 masing-masing adalah 0,030 ; 0,$029 ; 0,016 ; 0,014 ; 0,013 ; 0,012$ dan $0,008 \mathrm{ppm}$. Hal ini menunjukkan bahwa diklorometan memiliki toksisitas lebih rendah dari endosulfan.

Menurut Edwars (1975) dalam Rompas (1979), pestisida golongan organoklorin dapat menyebabkan penipisan membran insang ikan, mengurangi osmoregulasi, menyebabkan rendahnya jumlah butiran darah, merusak otak dan menurunkan berat badan serta dapat menyebabkan daya tahan ikan terhadap penyakit menjadi rendah dan gairah untuk makan berkurang. Bahkan pada dosis yang berlebihan tetapi belum mematikan, akan menimbulkan pengaruh akut yang merangsang sistem saraf pusat, dengan akibat menimbulkan kejangkejang dan pengaruh kronisnya bisa sampai generasi berikut yang menyerang hati dan saluran pembuangan.

Pengamatan tingkah laku hewan uji selama penelitian memperlihatkan perubahan tingkah laku hewan uji ketika terkontami- nasi bahan uji, dimana nener bandeng yang sehat apabila berada dalam wadah akan bergerak aktif, berenang searah jarum jam dan berada di atas permukaan air. Namun, ketika dimasukkan bahan uji dengan konsentrasi 0,75 dan $0,95 \mathrm{ppm}$, pada jam ke-3 hewan uji tampak mulai berlekuk, gerakannya menjadi kacau/kejang-kejang dan mulai turun ke dasar wadah percobaan. Hal ini diduga menunjukkan aktivitas insektisida organoklorin terhadap sistem saraf. Sebab insektisida organoklorin menyerang pada bagian saraf yang menimbulkan kejang-kejang (Edward, 1975 dalam Rompas, 1979).

Informasi mengenai pengaruh diklorometan terhadap organisme laut masih kurang (berdasarkan pustaka yang ditelusuri). Kebanyakan penelitian tentang pengaruh diklorometan diujicobakan pada hewanhewan darat seperti tikus, mencit dan anjing. Svirbely $d k k$, (1947) dan Von Oettingen dkk, (1991) dalam Hayes dan Laws (1991) melaporkan bahwa nilai-nilai standar untuk LC-50 pada 7-8 jam dengan mengunakan hewan uji tikus memiliki kisaran konsentrasi dari 8.000-15.000 ppm. Diklorometan berpotensi menghasilkan kerusakan-kerusakan hati dan ginjal. Pada pengunaan yang akut yaitu pada konsentrasi $13.500 \mathrm{ppm}$ uap diklorometan dapat menghasilkan anesthesia serta dapat menimbulkan kematian (Gehring, 1968 dalam Hayesdan Laws, 1991).

Ada sejumlah faktor yang mempengaruhi toksisitas pestisida terhadap ikan dan organisme air. Faktor-faktor tersebut adalah suhu, umur organisme, lamanya organisme dalam media yang tercemar serta jumlah pestisida terlarut. Namun, dari hasil yang didapat faktor lingkungan tidak berpengaruh dalam penelitan. Suhu selama penelitian berkisar antara $24-26^{\circ} \mathrm{C}$, salinitas $15 \%$ dan $\mathrm{pH} 7$, pengukuran tersebut dilakukan tiap jam pengamatan.

Dalam banyak kasus walau tidak secara umum, suhu yang tinggi akan menyebabkan meningkatnya toksisitas pestisida (Mc Ewen dan Stephenson, 1979). Dalam penelitian ini barangkali suhu tidak berpengaruh sebab perubahan suhu di perairan (media uji) tidak menunjukkan perubahan yang drastis. Suhu selama penelitian $24-26^{\circ} \mathrm{C}$, perubahan suhu relatif kecil se- 


\section{Insektisida Diklorometan pada Nener Bandeng}

hingga pengaruhnya terhadap toksisitas pestisida ini kemungkinan kecil.

Wardojo (1977) menyatakan bahwa setiap organisme mempunyai suhu maksimum, optimum dan minimum untuk hidupnya. Menurut Pillay (1993), suhu optimum untuk ikan bandeng berkisar pada $20-30^{\circ} \mathrm{C}$ dan suhu yang dianjurkan adalah $15-40^{\circ} \mathrm{C}$ dengan salinitas $10-20 \%$. Kisaran salinitas selama penelitian masih layak untuk nener bandeng.

Dari hasil pengamatan selama pengujian nilai median lethal konsentrasi (LC50) untuk uji kontrol (0 ppm) memperlihat- kan bahwa semua hewan uji dapat bertahan hidup sampai jam ke-96.

\section{KESIMPULAN}

Median Lethal Konsentrasi (LC-50) dari insektisida diklorometan terhadap nener bandeng (Chanos-chanos Forsk) untuk jam ke-12 dan 24 adalah 0,786; 0,287 ppm.

Semakin bertambahnya waktu ada kecenderungan semakin kecil nilai konsentrasi mematikan, sedangkan semakin tinggi konsentrasi, maka semakin cepat pula terjadi kematian hewan uji.

Tabel 1. Data hasil pengamatan pada penentuan presentase mortalitas hewan uji bandeng (Chanos-chanos Forsk) dengan Bahan Uji Diklorometan (Insektisida Organoklorin).

\begin{tabular}{|c|c|c|c|c|c|c|c|c|c|c|c|c|c|c|c|c|c|c|c|c|c|}
\hline \multirow{3}{*}{$\begin{array}{c}\text { Wak- } \\
\text { tu } \\
\text { (Jam) }\end{array}$} & \multirow{3}{*}{$\begin{array}{c}\begin{array}{c}\text { Kon- } \\
\text { trol }\end{array} \\
\text { (ppm) }\end{array}$} & \multicolumn{20}{|c|}{ Konsentrasi (ppm) } \\
\hline & & \multicolumn{4}{|c|}{0,15} & \multicolumn{4}{|c|}{0.35} & \multicolumn{4}{|c|}{0,55} & \multicolumn{4}{|c|}{0.75} & \multicolumn{4}{|c|}{0.95} \\
\hline & & A & $\mathrm{B}$ & C & $x$ & A & B & $\mathrm{C}$ & $x$ & A & B & $\mathrm{C}$ & $x$ & A & $\mathrm{B}$ & C & $x$ & A & $\mathrm{B}$ & $\mathrm{C}$ & $x$ \\
\hline 3 & 0 & 0 & 0 & 0 & & 0 & 0 & 0 & & 0 & 0 & 0 & & 0 & 0 & 0 & & 0 & 0 & 0 & 0,00 \\
\hline 6 & 0 & 0 & 0 & 0 & 0,00 & 0 & 0 & 0 & 0,0 & 0 & 0 & 0 & 0 , & 1 & 1 & 1 & 1,0 & 1 & 1 & 13 & 5,00 \\
\hline 12 & 0 & 2 & 0 & 1 & 1,00 & 1 & 3 & 4 & & 2 & 1 & 4 & & 6 & 6 & 3 & 5, & 3 & 8 & 10 & 7,00 \\
\hline 24 & 0 & 3 & 0 & 1 & 1,33 & 6 & 6 & 9 & 7,00 & 10 & 6 & 10 & 8,67 & 10 & 10 & 10 & 10,00 & 10 & 10 & 10 & 10,00 \\
\hline 36 & 0 & 7 & 0 & 4 & 3,67 & 8 & 7 & 10 & 8,33 & 10 & 9 & 10 & 9 & 10 & 10 & 10 & 10 & 10 & 10 & 10 & 10,00 \\
\hline 48 & 0 & 8 & 0 & 4 & 4,0 & 10 & 9 & 10 & 9,6 & 10 & 10 & 10 & 10 & 10 & 10 & 10 & 10 & 10 & 10 & 10 & 10,00 \\
\hline 60 & 0 & 8 & 1 & 5 & 4,67 & 10 & 9 & 10 & 9,67 & 10 & 10 & 10 & 10,00 & 10 & 10 & 10 & 10,00 & 10 & 10 & 10 & 10,00 \\
\hline 72 & 0 & 8 & 1 & 5 & 4,6 & 10 & 9 & 10 & 9,67 & 10 & 10 & 10 & 10. & 10 & 10 & 10 & & 10 & 10 & 10 & 10,00 \\
\hline 96 & 0 & 8 & 2 & 6 & 5,33 & 10 & 9 & 10 & 9,67 & 10 & 10 & 10 & 10,00 & 10 & 10 & 10 & 10,00 & 10 & 10 & 10 & 10,00 \\
\hline
\end{tabular}

Ket.

A, B, C (ulangan); x (nilai rata-rata)

Tabel 2. Nilai median letal konsentrasi (LC-50) insektisida diklorometan dengan mingguna-kan nener bandeng (Chanos-chanos Forsk) sebagai hewan uji dianalisis dengan Probit.

\begin{tabular}{|c|c|c|c|}
\hline $\begin{array}{l}\text { Waiktu } \\
\text { (Jam) }\end{array}$ & $\begin{array}{l}\text { Persamaan Garis } \\
\qquad(Y=a+b x)\end{array}$ & $\begin{array}{l}\text { LC-50 } \\
\text { (ppm) }\end{array}$ & $\begin{array}{c}\text { (5\% Selang Kepercayaan } \\
\text { Untuk LC }-50 \text { (ppm) }\end{array}$ \\
\hline 3 & 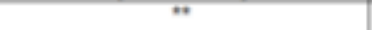 & $*$ & $*$ \\
\hline 6 & $*$ & $*$ & $*$ \\
\hline 12 & $Y=5,212+2,025 X \log ($ Kons $)$ & 0,786 & $0,510-3,712$ \\
\hline 24 & $Y=6.894+3.494 \times \log$ (kons) & 0.287 & $0.178-0.384$ \\
\hline 36 & 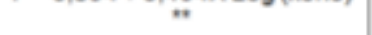 & $*$ & $n$ \\
\hline 48 & $*$ & $*$ & $*$ \\
\hline 60 & $*$ & $*$ & $*$ \\
\hline 72 & $*$ & $*$ & $*$ \\
\hline 96 & $*$ & $*$ & $*$ \\
\hline
\end{tabular}

\section{DAFTAR PUSTAKA}

Abel, 1991. Lethal toxicity test : theory and methodology. Hal 39-36 dalam P.D Abel dan Axiak (Ed) Ecotoxicology and the Marine Enviroment Ellis Horwood. New York.

Anonim, 1987. Teknik Budidaya Ikan Bandeng di Tambak. Dinas Perikanan Propinsi Daerah Tingkat I Jawa Timur. Surabaya. 39 hal.

Chapman, P.M. dan Long, E.R., 1983. The Use of Bioassay As Part of A Comprehen- sive Approach to Marine Pollution Assassment. Marine Pollution Buletin 14 (3).

Connel, D.W. dan Miller, G.J., 1984. Kimia dan Ekotoksikologi Pencemaran. Terjemahan Koestor, Y. Ul-press, Jakarta.

Cope, E.C., 1962. Organic Pesticides. Their Detection, Measurement and Toxicity to Aquatic Life : 245 - 246.

Dinnel, P.A., 1994. Toxicity Testing in The Marine Enviroment. Marine Science Education Project. Local Project Implementation Unit. University of Riau, Pekanbaru. 42 hal. 
Fessenden, R.J. dan Fessneden, J.S., 1989. Organic Chemistry. Third Edition. Wadsworth, Inc. USA.

Finney, D.J., 1971. Probit Analysis Third Edition. Cambridge University. Perss London. 333 hal.

Hays, W.J. dan Law, E.R., 1991. Solvents, Fumungants, and Related compounds: Dichloromethane. Hal 671-674 dalam Handbook of Pesticide Toxicology. Volume 2 Classes of Pesticides. Academy Press, Inc. San Diego. New York. Boston. London. Sydney. Tokyo. Toronto.

Heath, A.G., 1987. Water Pollutin and Fish Physiology CRC. Press Boca Raton. Ann Arbor. London.

Inversen, E.S., 1968. International Fisheries and Marine Pollution of the ea. 7-9 th, Oct 1968. Paper (1) : 29-49.

Jones, N.R.E., 1964. Fish River Pollution. Butter Woter London ; 203 pp.

Kok, L.T., 1972. Toxicity of Insecticides Use for Asia Rice Borrer Control to Tropical Fish. In Rice Padies Garden City, New York : 489-498.

Manahan, S.E., 1992. Ttoxicology Chemistry. Second edition. Lewis Publisher Boca Raton Arbor. London.
Martosudarmo, 1984. Biologi Bandeng dan Pedoman Budidaya Tambak. Direktorat Jendral perikanan Departemen Pertanian. 223 hal.

Mujiman, A. dan Suyanto, S.R., 1987. Budidaya Bandeng di Tambak. PT. Penebar Swadaya. Jakarta. 103 hal.

Murty, A.S., 1986. Toxicity Of Pesticide To Fish. Volume I. CRC Press Florida.

Petrucci, R.H, 1999. Kimia Dasar. Edisi Keempat Jilid I. Terjemahan Suminar. Penerbit Erlangga. Jakarta.

Rand G.M. dan Petrocelli, R.S., 1985. Fundamental Of Aquatic Toxicology. Hemisphere Publishing Coorporation. New York.

Rompas R.M. dan Sunaryo, P., 1989. Toksikologi Pestisida. Bahan Penataran Toksikologi di Unsrat. Kerjasama UNSRAT-CIDA/SFE. Proyek Pengembangan Perguruan Indonesia Timur.

Thompson, R.C.M., 1973. Pesticides and Fresh Water Fauna. Academic Press. London, New York. 248 pp

Wardojo, S.T.M., 1987. Pengaruh Pestisida Terhadap Kehidupan Perairan. Lembaga Pusat Penelitian.Bogor. 292 hal. 